\title{
PELAYANAN KONSELING MELALUI KOMUNIKASI KELOMPOK UNTUK PENGURANGAN RISIKO BENCANA BAGI SISWA SEKOLAH AMAN BENCANA DI KOTA BOGOR JAWA BARAT
}

\author{
Damayanti Wardyaningrum ${ }^{*}$, Radhiya Bustan ${ }^{2}$ \\ ${ }^{\text {I}}$ Program Studi Ilmu Komunikasi, Fakultas Ilmu Sosial dan Ilmu Politik, Universitas Al Azhar \\ Indonesia, Jalan Sisingamangaraja, Kebayoran Baru, Jakarta Selatan 12110 \\ ${ }^{2}$ Program Studi Psikologi, Fakultas Psikologi dan Pendidikan, Universitas Al Azhar Indonesia, \\ Jalan Sisingamangaraja, Kebayoran Baru, Jakarta Selatan 12110 \\ Email Penulis Korespondensi: damayanti@uai.ac.id
}

\begin{abstract}
Abstrak
Kota Bogor merupakan salah satu wilayah yang rentan bencana gempa bumi, banji dan tanah longsor. Paradigma bencana kini yang harus dibangun adalah pengurangan risiko, dan fokus kedepan adalah kesiapsiagaan masyarakat terhadap bencana sehingga harus ditumbuhkan kemandirian dan kesadaran individu. Oleh karenanya kesiapsiagaan bencana harus diperkenalkan sejak usia dini dan terus menerus sesuai kapasitas komunitas. Kegiatan pengabdian masyarakat berbasis penelitian ini bertujuan untuk meningkatkan kapasitas komunitas dengan memelihara ingatan serta meningkatkan kepedulian siswa dan guru tentang kesiapsiagaan menghadapi bencana. Metode yang digunakan konseling melalui komunikasi kelompok yang diawali dengan wawancara guru dan siswa, pengamatan terhadap lingkungan sekolah yang dekat sungai Ciliwung dan rawan longsor di Sekolah Dasar Negeri Sempur Kota Bogor Jawa Barat. Kegiatan konseling dilakukan melalui permainan kelompok (ular tangga, dan kartu pesan bencana), dan drama musikal. Dari konseling melalui komunikasi kelompok, siswa memperoleh beberapa manfaat yaitu: pemenuhan identitas diri, pertukaran informasi, kesempatan menunjukkan kreativitas, mengenal inovasi tentang informasi bencana serta belajar tentang perbedaan peran dalam pertolongan bencana.
\end{abstract}

Kata kunci: Bencana, Komunikasi Kelompok, Pelayanan Konseling

\begin{abstract}
Bogor is one the most vulnerable areaof natural disaster in West Java of earthquake and landslide. The aim of this activity is to build the capacity of local community starting from elementary school to the student, teacher and also their community. The school of Sekolah Dasar Sempur Keler Bogor located between big river and landslide. The activity base on preleiminary research with interviewing to the local government of disaster anagement, teacher and students. Methode use in the activity with framework of group communication in counselling services. Theme of the activity is bulding disaster preapardenes by using some disaster games with card and art performance. From the service community activity which base on research students not only have some benefiaciary in some knowledge, fulfill their identity, sharing information, performing their creativity, recognizing the inovations of disaster information, and playing role for the disaster helpness.
\end{abstract}

Keywords : Counseling Services, Grup Communications, Disaster.

\section{PENDAHULUAN}

Jenis bencana yang paling tinggi di Indonesia dari segi frekuensi adalah bencana hidrometeorologi. Bencana hidrometeorologi adalah bencana yang terjadi karena dipengaruhi oleh faktor cuaca. Bencana yang dimaksud meliputi banjir, tanah longsor, puting beliung, 
kekeringan, kebakaran hutan dan lahan, dan gelombang pasang serta abrasi. Setiap tahunnya presentase bencana hidrometeorologi yang terjadi lebih dari 80 persen. Bencana hidrometeorologi dapat dikatakan merupakan bencana rutin. Namun intensitas dampak kerusakan bencana hidrometeorologi relatif kecil jika dibandingkan dengan bencana geologi seperti letusan gunung api, gempa bumi, dan tsunami yang frekuensinya lebih sedikit (BNPB, 2014).

Beberapa kota dan kabupaten di Jawa Barat termasuk wilayah yang memiliki kerawanan tinggi rawan bencana. Kota Bogor termasuk kedalam tingkat tinggi berdasarkan ancaman bencana gempa bumi, tanah longsor, kekeringan dan cuaca ekstrem (BNPB, 2014). Kota Bogor merupakan salah satu kota di Jawa Barat dengan kondisi geografis yang mayoritas perbukitan dan kontur tanah yang labil. Kini dengan semakin meningkatnya kepadatan penduduk, menjadikan Kota Bogor rentan hingga berpotensi mengalami berbagai jenis bencana seperti bencana banjir, gempa bumi, angin puting beliung, tanah longsor dan ancaman gunung meletus berpotensi terjadi di wilayah Kota Bogor (Syamsiah, 2017)

Salah satu penelitian Nasution dalam Sunarti dkk (2013:76) mengemukakan juga tentang tingginya kejadian korban dan bencana longsor serta masih lemahnya manajemen bencana di Indonesia, yang disebabkan oleh kurangnya dana, otoritas kelembagaan dan sumberdaya manusia dalam manajemen bencana sehingga memerlukan suatu paradigma baru manajemen bencana berbasis komunitas yang dapat memberdayakan potensi masyarakat daerah rawan bencana dalam mengantisipasi bencana melalui kesiapsiagaan bencana. Hasil dari kajiannya yang menggunakan pendekatan budaya masyarakat menunjukkan bahwa hampir 90 persen warga Desa Kidangpananjung memiliki hubungan darah yang sangat dekat. Sistem kekerabatan yang terjalin diantara sesama anggota masyarakat dan sifat solidaritas yang tinggi untuk saling menolong merupakan modal sosial yang dapat diberdayakan dalam mewujudkan kesiapsiagaan bencana berbasis komunitas.

Namun demikian di sebagian besar wilayah yang rawan bencana alam di Indonesia, masyarakatnya ternyata belum kerentanan dan kapasitasnya dalam menghadapi potensi bencana. Salah satu contoh adalah kajian Sinulingga dkk (2014) tentang Kepemerintahan
Bencana di proponsi Sumatera Barat ditemukan bahwa peranan masyarakat di Sumatera Barat dalam isu kebencanaan relatif masih kecil, tidak massif, dan kurang memadai untuk menciptakan masyarakat tangguh terhadap bencana. Sehingga perlu dibangun pemahaman bagi masyarakat bahwa meskipun bencana sendiri menuntut keterlibatan multi aktor dan multi sektor.

Hasil kajian diatas kiranya merupakan gambaran tentang kapasitas nasional terutama ketangguhan masyarakat merupakan prasayarat menuju masyarakat dan negara tangguh terhadap bencana alam. Masyarakat tidak dipandang sebagai penerima manfaat (beneficiaries) atau pelaksana dari programprogram yang disusun oleh pemerintah dan lembaga internasional, namun masyarakat menjadi inisitaor dari program-program dalam aksi penanggulangan bencana serta dilibatkan dalam perumusan setiap regulasi, kebijakan dan program-program kemanusiaan tersebut.

Sebagai contoh adalah berangkat dari kajian tentang identifikasi kerawanan wilayah terhadap bencana. Salah satu rekomendasi yang di sarankan dari hasil penelitian terhadap wilayah yang rawan longsor adalah diperlukan peningkatan kapasitas untuk mitigasi bencananya dalam bentuk fisik/infrastruktur dan non-fisik, pembangunan infrastruktur tersebut antara lain: a. Untuk wilayah yang berisiko tinggi direkomendasikan untuk relokasi ke tempat yang aman. Pembangunan rumah untuk relokasi dengan menggunakan konsep bangunan tahan gempa. b. Untuk wilayah yang berisiko sedang direkomendasikan adanya pembagunan dinding penahan tanah, saluran drainasi dan penanaman pohon (Aminatun dan Muntafi, 2017). Jika jenis ancaman di satu wilayah telah diketahui, maka selanjutnya harus dilakukan sosialisasi kepada masyarakat tentang pentingnya meningkatkan kapasitas setiap individu yang dimulai sejak usia dini hingga dewasa.

Dengan paradigma penanggulan bencana menuju paradigma mitigasi, preventif sekaligus juga paradigm pembangunan maka pemberdayaan masyarakat harus ditingkatkan untuk lebih mengetahui tentang kebencanaan serta karakteristik wilayah masing-masing dari ancaman bencana (Saptadi \& Djamal, 2012). Paradigma ini menjadi penting agar dilakukan pendidikan berkesinambungan dalam meningkatkan pemahaman masyarakat tentang kerentanan wilayahnya masing-masing terhadap 
risiko bencana alam (Sunarti, Sumarno, \& Johan, 2013) menekankan dalam kajiannya tentang kapasitas masyarakat menghadapi risiko bencana bahwa salah satu langkah awal dalam membangun ketanguhan bangsa dan masyarakat terhadap bencana adalah mengidentifikasi dan menganalisis kerentanan bangsa dan masyarakat sebagian besar masyarakat Indonesia di wiyah yang rawan bencana Menurut ilmu sosial, kerentanan (vulnerability) merupakan kebalikan dari ketangguhan (resilience), dimana kedua konsep tersebut laksana dua sisi mata uang. Kerentanan, ketangguhan, kapasitas, dan kemampuan merespon dalam situasi darurat, bisa diimplementasikan baik pada level individu, keluarga, masyarakat, dan institusi seperti pemerintah maupun NGO.

Kegiatan pengabdian masyarakat berbasis penelitian ini bertujuan untuk meningkatkan kapasitas komunitas dengan memelihara ingatan serta meningkatkan kepedulian siswa dan guru berikut kelompok pendukungnya tentang pentingnya memiliki pengetahuan dan pengalaman tentang kesiapsiagaan menghadapi bencana, memahami kerentanan dan kapasitas yang dimiliki sebagai kelompok masyarakat yang rentan terdampak bencana.

\section{Pelayanan Konseling}

Bentuk konseling yang sering digunakan pada usia 5-9 tahun ini adalah konseling bermain, karena bermain merupakan cara yang natural bagi anak untuk mengekspresikan diri dan anak memperoleh kesempatan untuk play out perasaan-perasaan dan masalahnya.

Manfaat bermain dalam konseling :

a. Memahami karakteristik anak: kapasitasnya untuk berhubungan dengan orang lain, rigiditas, preokupasi, harapan, ide-ide,dll

b. Membentuk hubungan kerja, terutama bagi anak yang kapasitas verbalnya masih terbatas.

c. Mengetahui cara anak berhadapan dengan situasi sehari-hari dan defens terhadap kecemasan.

d. Membantu anak mengungkapkan hal-hal tertentu serta perasaan yang menyertainya.

e. Membantu anak mengekspresikan hal-hal pada ketidaksadaran dan mengurangi tekanan.

f. Mengembangkan minat bermain pada anak yang dapat digunakan pada masa-masa selanjutnya.
Cara lain yang sering digunakan untuk konseling pada anak usia 5-9 tahun ini adalah dengan Friendship Group, dengan ciri-ciri:

a. Kelompok bersifat heterogen, terdiri dari 6 anak (2 laki dan 4 perempuan)

b. Pemilihan anggota berdasarkan pada perbedaan minat dan karakteristik kepribadian

c. Pada dasarnya melalui kelompok ini anak belajar mengenal arti persahabatan serta aturan-aturan penting dalam hubungan persahabatan.

d. Mereka diminta mengobservasi teman kelompoknya, bermain peran, berdiskusi mengenai minat dan kelebihan masingmasing dan kemudian ditutup dengan pengungkapan kesan-kesan dari pertemuan mereka.

\section{Seni dalam konseling}

Gumaer (1984) mengemukakan seni dapat bermanfaat bagi anak dalam hal:

a. Seni melibatkan anak untuk menggunakan pikiran dan panca inderanya. Mereka dilatih untuk menggabungkan berbagai input untuk

b. menjadi produk yang terintegrasi

c. Anak dapat mengekspresikan pikiran dan perasaannya yang berhubungan dengan masa lalu, saat ini maupun masa depan

d. Seni memungkinkan anak untuk melakukan katarsis dari emosi-emosi negatif dalam bentuk yang dapat diterima lingkungan

e. Seni merupakan produk hasil inisiatif diri dan dikontrol oleh anak sehingga meningkatkan perkembangan ego

f. Proses penciptaan seni memberikan perasaan telah berprestasi, kepuasan dan harga diri

g. Seni dapat membantu pembentukan rapport dengan anak-anak yang pemalu, ragu-ragu dan non verbal

h. Melalui seni terapis dapat menyentuh aspek bawah sadar pada anak tanpa harus berhadapan dengan mekanisme defensnya

i. Seni memberikan tambahan data diagnostik bagi informasi lain yang diperoleh dalam konseling.

\section{Komunikasi Kelompok}

Kelompok adalah kumpulan dari individuindividu, sehingga pembahasan mengenai kelompok antara lain dapat meninjau ide dari McGrath yang dikutip oleh Poole (1999), tentang keseimbangan antara individu dan kelompok. Pemikiran McGrath menekankan bahwa terdapat hubungan antara individu dan 
kelompok yang saling memenuhi kebutuhan sehingga kepuasan individu mutlak harus dapat dipenuhi agar keberadaan kelompok dapat terpelihara. Hal lainnya yang menjadi fokus pada konsep ini adalah bagaimana individu yang membawa "kepribadian masing-masing" dapat menjadikan kelompok sebagai bagian dari identitas dirinya. Selanjutnya terdapat fakta bahwa jarang sekali individu hanya menjadi anggota dari satu kelompok. Hal ini memberi peluang adanya pertukaran informasi, kreativitas dan inovasi yang diperoleh dari kelompok lain. Elemen lain yang juga penting untuk diperhatikan adalah adanya perbedaan peran dari setiap individu dalam organisasi. Perbedaan peran ini menimbulkan kompleksitas dalam organisasi yang disatu sisi dapat memaksimalkan potensi kelompok namun disisi lain juga dapat menimbulkan konflik (Polee, 1999).

Uraian diatas menunjukkan bahwa unsur dari komunikasi kelompok adalah individu dimana setiap individu memiliki begitu banyak bagian. Dari individu maka hubungan antara satu individu dengan individu yang lainnya dapat merupakan kajian tersendiri dengan segala kompleksitas didalamnya. Dalam konteks yang lebih besar maka individu-individu yang terdapat dalam kelompok memberikan kontribusi bagi kelompoknya baik dalam hal pemuasan kebutuhan anggota kelompok, perkembangan kelompok, ketahanan kelompok, hingga konflik. Sehingga penting untuk ditekankan mengetahui karakter individu dalam kelompok guna memberikan gambaran tentang sebuah kelompok termasuk interaksi dan komunikasi individu dalam kelompok.

Pendapat (Littlejhon \& Foss, 2009) bahwa teori teori tentang komunikasi kelompok bertujuan untuk mengembangkan pengetahuan praktis tentang perilaku kelompok yang dapat memandu fasilitator kelompok maupun anggota kelompok. Sehingga teori tersebut digunakan untuk mempelajari jenis kelompok umum maupun kelompok yang dibuat dengan dengan tujuan tertentu. Yaitu kelompok yang dibentuk untuk pengambilan keputusan dan kelompok yang berorientasi pada tugas.

Pada kelompok biasanya terdapat lima tahapan yang biasanya dilalui oleh kelompok dalam mencapai tahap pengambilan keputusan yaitu 1) analisa masalah 2) Menentukan kriteria yang digunakan untuk evaluasi 3) Mengembangkan alternatif solusi 4) Melakukan evaluasi terhadap konsekuensi positif dan 5)
Melakukan evaluasi terhadap konsekuensi negatif yang mungkin akan terjadi (Miller:2005).

Pada tahap pertama kelompok berusaha melakukan pengembangan dan identifikasi secara akurat masalah yang akan diselesaikan. Tahap ini sangat penting karena seringkali kelompok tidak dapat melakukan identifikasi masalah dengan tepat, atau tidak dapat melihat masalah yang sebenarnya. Pada tahap kedua kelompok berusaha mencapai kesepakatan untuk menentukan secara tepat kriteria apa saja yang akan digunakan untuk mengambil keputusan. Tahap ketiga adalah tahap dimana kelompok dapat mengasilkan beberapa alternatif pilihan yang dapat diterima oleh kelompok. Pada tahap keempat dan kelima, kelompok melakukan evaluasi terhadap kemungkinan timbulnya konskuensi negatif maupun konsekuensi positif yang timbul dari setiap pilihan alternatif yang ada.

Disinilah maka peran komunikasi kelompok menjadi amat penting. Karena disetiap tahapan proses pengambilan keputusan komunikasi dilakukan dengan saling memberikan informasi diantara anggota kelompok, mempertimbangkan pendapat anggota terhadap alternatif pilihan yang ada dan selanjutnya secara bersama-sama mengembangkan berbagai macam alternatif pilihan. Anggota kelompok tentunya masingmasing memiliki keinginan untuk menyampaikan pendapatnya, namun disisi lain juga perlu memberi kesempatan anggota lain untuk menyampaikan berbagai macam gagasannya. Sehingga Poole menegaskan bahwa proses inilah yang akan menjadikan pengambilan keputusan mencapai kualitas yang terbaik.

Beberapa konsep dalam teori fungsional juga penting untuk mendukung komunikasi kelompok. Benne dan Sheats seperti dikutip dalam (Pace \& Faules, 1994) memperkenalkan dan menggolongkan peranan fungsional yang dilakukan oleh anggota kelompok dan tim kedalam tiga kategori besar.Pertama, peranan yang memperlancar pengaruh kelompok dalam pemecahan masalah (peranan tugas). Kedua, peranan yang mempertahankan, memperkuat, mengatur dan terus menerus menghidupkan kelompok atau tim (peranan pemeliharaan). Ketiga, peranan yang mengganggu kemajuan dan usaha kelompok dengan menonjolkan pemenuhan kebutuhan perorangan yang tidak relevan atau bertentangan dengan penyelesaian 
tugas dan pemeliharaan kelompok (peranan mengganggu).

Lebih jauh lagi pendekatan fungsional digunakan dalam konsep pengambilan keputusan dalam komunikasi kelompok. Konsep ini menekankan bahwa hampir sebagian besar proses pengambilan keputusan dilakukan dalam kelompok. Baik itu dalam kelompok bisnis maupun dalam bidang pemerintahan. Meskipun penelitian ini tidak akan menggali secara khusus tentang pengambilan keputusan dalam kelompok, namun kiranya perlu untuk dipahami bahwa salah satu keberlangsungan suatu kelompok adalah kemampuannya dalam melakukan pengambilan keputusan. Salah satu pendekatan yang digunakan dalam konsep ini adalah dari pendekatan fungsional menurut Hirokawa \& Salazar (Polee, 1999).

Dari pendekatan fungsional argumentasi yang dikemukakan Riecken dalam Hirokawa \& Salazar adalah bahwa interaksi yang terjadi antar individu dalam kelompok akan berdampak pada kualitas keputusan yang diambil (Polee, 1999). Dalam hal ini anggota kelompok saling mempersuasi anggota lainnya dengan komunikasi. Sehingga dapat diperoleh suatu pandangan yang sama dan menggunakan informasi yang dikontribusikan.

Salah satu konsep awal dari teori fungsional berasal dari Beles's Equilibrium Theory (Polee, 1999) yang mendukung uraian diatas menekankan bahwa kelompok yang efektif harus dapat memenuhi dua kebutuhan yaitu fungsi tugas dan fungsi kebutuhan emosi sosial anggotanya, dengan cara menjaga keseimbangan antara keduanya. Fungsi kelompok sebagai pemenuhan tugas akan membawa implikasi terhadap proses pengambilan keputusan - orientasi, evaluasi, dan kontrol- yang memberikan sejumlah tindakan untuk menyelesaikan suatu masalah yang harus diputuskan dalam kelompok. Konsekuensi lainnya maka berbagai persoalan emosi sosial akan timbul sebagai akibat dari timbulnya ketidaksetujuan pendapat antar anggota dan ketegangan yang muncul sebagai dampak dari orientasi anggota kelompok yang lebih berfokus pada beban tugas atau pekerjaan daripada hubungan antara anggotanya. Kondisi sosial emosional anggota kelompok sebaiknya dapat dikelola dalam bentuk ungkapan gurauan, atau ada sarana pelepas stress. Karena jika tekanan emosi sosial ini tidak dikelola dari waktu kewaktu dapat menurunkan produktivitas kelompok secara keseluruhan. Disisi lain keseimbangan antara fungsi tugas dan pemenuhan kebutuhan sosial emosional perlu dicermati terutama pada periose-periode transisi (Polee, 1999).

\section{METODE PELAKSANAAN}

\section{Ruang Lingkup}

Kegiatan pengabdian masyarakat dilakukan di Sekolah Dasar Negeri Sempur Kota Bogor Jawa Barat. Wilayah sekolah ini juga berdekatan dengan lingkungan tempat tinggal siswa dan penduduk lainnya. Kerawanan bencana di wilayah ini adalah posisinya yang berada di daerah rawan longsor serta lokasi gedung sekolah berdekatan dengan daerah aliran sungai Ciliwung.

Kegiatan dilaksanakan antara bulan Desember 2017 hingga April 2018 yang meliputi observasi dan wawancara ke pihak sekolah, penyusunan materi hingga pelaksanaan kegiatan puncak. Alat peraga yang digunakan antara lain kartu permainan pengetahuan seputar bencana, permainan ular tangga dengan tema mitigasi bencana dan atraksi drama musikal dengan tema tanggap darurat bencana.

\section{Target Peserta Kegiatan}

Target peserta kegiatan ini dibagi menjadi dua kelompok yaitu target primer dan target sekunder. Tujuan pembagian kelompok ini adalah agar sasaran dari kegiatan dapat berjalan secara optimal dan dapat dievaluasi secara menyeluruh. Adapun target primer kegiatan adalah siswa sekolah dan guru .

Sedangkan target peserta kegiatan sekunder kegiatan adalah orangtua siswa yang diwakili oleh komite sekolah serta melibatkan Babinsa dan Kamtibmas. Masyarakat yang merupakan target sekunder ini adalah sebagai kelompok pendukung dari siswa dan guru dalam melaksanakan tindakan sebagai sekolah aman bencana dalam upaya pengurangan risiko bencana. Metode yang diterapkan adalah dengan wawancara dan berbagai kegiatan interaktif menggunakan games untuk target peserta siswa sekolah dasarsebagai pendukung metode yang diterapkan bagi kelompok primer.

\section{Tahapan Kerja Pengabdian Masyarakat}

Kegiatan Pelayanan Konseling melalui Komunikasi Kelompok pada siswa sekolah dasar ini bekerjasama dengan pihak Badan 
Penangulangan Daerah (BPBD) kota Bogor dan dilakukan dengan tahapan sebagai berikut:

Pertama, survei awal adalah kegiatan kunjungan ke lokasi berdasarkan informasi dari mitra BPBD Kota Bogor bahwa telah dilaksanakan pembinaan pada salah satu sekolah dasar tentang sekolah aman bencana. Di lokasi sasaran dilakukan wawancara kepada kepala sekolah, guru dan observasi lokasi sekolah rawan longsor karena berdekatan dengan sungai dan tebing.

Kedua, survei lanjutan ke lokasi dengan melakukan wawancara lebih mendalam kepada guru pembina siswa mengenai kegiatan sekolah aman bencana yang selama ini dilakukan serta wawancara kepada anak-anak kelompok target sasaran kegiatan. Ditemukan bahwa hanya beberapa anak yang selama ini mengikuti kegiatan sosialisasi sekolah aman bencana dan berharap lebih bnayak siswa yang bisa mengikuti sosialisasi serta berharap kegiatan lebih dikembangkan.

Ketiga, berdasarkan hasil survey awal dan lanjutan dilakukan penyusunan instrument dalam bentuk pelayanan konseling yang dirangkai dalam bentuk komunikasi kelompok. Pertimbangan pemilihan instrument ini adalah karena siswa sekolah dasar dilokasi ini memiliki ikatan yang sangat kuat dengan teman-temannya dan beberapa anak yang memiliki potensi dalam bidang seni dapat memberikan pengaruh pada teman-teman lainnya.

Keempat, dilakukan pretest terhadap instrument tentang pelayanan konseling melalui komunikasi kelompok. Dilakukan beberapa kali latihan kepada anak-anak yang menjadi target kegiatan, kemudian dibuat perbaikan instrument yang idisesuaikan dengan kebutuhan siswa.

Kelima, dilaksanakan kegiatan pelayanan konseling dengan menggunakan metode komunikasi kelompok. Siswa dibagi menjadi beberapa kelompok dan setiap kelompok didampingi oleh tim fasilitator serta guru pendamping. Siswa dilibatkan untuk memahami peristiwa bencana dan dilakukan dialog dengan kelompoknya berupa pertanyaan yang dikemas dalam bentuk pemainan. Tim fasilitator akan membantu mengarahkan aktifitas kelompok dan memberikan penjelasan tentang hal-hal yang belum diketahui atau memberikan jawaban atas pertanyaan-pertanyaan yang dilontarkan oleh siswa,

Keenam, selama kegiatan berlangsung tim fasilitator mencatat perilalu siswa dari segi keaktifan, pertisipasi, peran yang dijalankan, serta keterlibatan dalam kelompok. Dari seluruh catatan tersebut maka dilkaukan analisa terhadap respon siswa secara umum sehingga diperoleh gambaran untuk dilakukan pengembangan program berikutnya. Pada tahap selanjutnya diharapkan dapat dilakukan kegiatan untuk lebih memfokuskan siswa dalam membangun pengetahuan terkait kerentanan dan kapasistas

\section{HASIL DAN PEMBAHASAN}

Dalam rangka rangkaian pelaksanaan kegiatan pengabdian masyarakat di SDN Sempur Kaler Kota Bogor, tim Universitas Al Azhar Indonesia (UAI) berkesempatan melaksanakan survei pendahuluan kepada beberapa pihak yaitu, BPBD Kota Bogor, Guru Pembina Siswa SDN Sempur Kaler dan beberapa siswa Siswa SDN Sempur Kaler.

a. Pertemuan tim pengabdian masyarakat UAI dengan pihak Badan Penanggulangan Bencana Kota Bogor dengan Ibu Nurma Syamsiah, M.Si, memperoleh gambaran tentang berbagai kegiatan yang pernah dilakukan oleh BPBD Kota Bogor yang diantaranya membangun kemitraan dengan pihak sekolah dasar. Tujuannya adalah membangun kesadaran akan kesiapsiagaan tentang bencana sejak usia dini. Selain itu karena di wilayah Kota Bogor rawan bencana longsor dan banjir maka pihak BPBD kota Bogor sangat fokus dengan penanggulangan bencana pada jenis ancaman bencana banjir dan longsor.

b. Survei ke sekolah SD Negeri Sempur Kaler dilaksanakan pada bulan Januari dan Maret 2018. Dari hasil survei awal diperoleh gambaran tentang kegiatan pengurangan risiko bencana yang telah disosialisasikan oleh BPBD Kota Bogor dua tahun yang lalu. Kegiatan Pengabdian Masyarakat yang digagas oleh UAI merupakan kegiatan yang sangat mendukung kelanjutan kegiatan sosialisasi tentang pengurangan risiko bencana kepada siswa SDN Sempur Kaler. Dari penjelasan guru pembina kegiatan siswa dan pembimbing teater siswa Ibu Euis, bahwa selama ini dari pihak sekolah hanya terdapat sekitar lima orang anak yang pernah diikut sertakan sebagai perwakilan dalam kegiatan di wilayah pemerintah daerah setempat. Sehingga kegiatan pengabdian masyarakat yang digagas oleh UAI memberikan manfaat lebih luas yaitu 
dikitsertakannya lebih banyak siswa SDN Sempur Kaler yang akan dilibatkan dalam sosialisasi pengurangan risisko bencana khususnya bencana banjir dan longsor.

Dari hasil pengamatan lokasi sekolah diperoleh gambaran tentang risiko bencana di wilayah ini yaitu :

a. Letak sekolah disalah satu sisinya berada disekeliling perumahan yang dibelakangnya terdapat lembah dengan kemiringan hampir 90 derajat. Meskipun terdapat pepohonan pada sekeliling lembah yang dapat mengurangi risiko longsor, namun dikhawatirkan jika terjadi hujan dengan intensitas kelebatan yang tinggi secara terus menerus maka ancaman longsor bisa terjadi.

b. Pada sisi yang lain terdapat sungai terusan sungai Ciliwung yang lebar permukaannya sekitar 20 meter dengan aliran sungai yang deras dan dasarnya berbatu-batu. Sungai ini terletak sekitar $8 \mathrm{~km}$ dari bending Katulampa kota Bogor yang merupakan salah satu indikator terjadinya banjir di Jakarta jika terjadi hujan di wilayah Bogor dan Puncak. Perkiraan banjir di Jakarta biasanya diprediksi akan terjadi 5 jam setelah bending Katulampa dinayatakan siaga 1 . Sungai yang berada disamping sekolah disisi yang lain merupakan pemukiman penduduk dimana sebagian siswa SDN Sempur Kaler tinggal.

c. Dari hasil wawancara dengan beberapa siswa diperoleh penjelasan bahwa sebagian dari anak-anak tinggal diwilayah yang rawan banjir. Beberapakali banjir terjadi di wilayah mereka dan anak-anak sudah diajarkan bagaimana cara mengkomunikasikan kepada pihak tertentu seperti teman atau gurunya jika ada tanda-tanda banjir yang dating. Beberapa siswa sudah dapat menggunakan alat komunikasi digital dan menyampaikan pesan secara efektif kepada teman dan gurunya jika diwilayah tempat tinggalnya akan terjadi banjir. Jika banjir datang maka siswa tidak dapat pergi ke sekolah hingga banjir surut. Karena banjir menggenangi jalan menuju sekolah mereka.

Dari hasil survey dan wawancara kepada pihak BPBD dan guru Pembina maka diputuskan bahwa kegiatan puncak sosialisasi dalam bentuk kampanye melalui komunikasi kelompok akan dilaksanakan pada tanggal 7 Apil 2018 di SDN Sempur Kaler, Kota Bogor. Bentuk kegiatan yang direncanakan terdiri dari:

1. Penampilan 'pantomim' mengenai evakuasi bencana kebakaran dan drama musikal mengenai prosedur evakuasi banjir yang dilakukan oleh SDN Sempur Kaler bekerja sama dengan BPDB Bogor.

2. Permainan ular tangga dan kartu kuartet secara berkelompok dengan fasilitator mahasiswa UAI. Permainan Ular Tangga, siswa/i kelas 4 dan 5 dibagi menjadi 4 kelompok dengan jumlah satu kelompok 7 orang. Permainan kelompok ini berisi tematema tentang kesiapsiagaan bencana, dalam bentuk gambar berwarna warni, pesan-pesan tentang bencana dan kerjasama kelompok dalam menjawab pertanyaan yang diajukan.

\section{Kegiatan Pelayanan Konseling Melalui Komunikasi Kelompok}

Hari Sabtu, 7 April 2018 bertempatan di SDN Sempur Kaler, Bogor tim yang terdiri dari 2 tenaga pengajar dan 4 mahasiswi program studi Psikologi dari UAI menggelar kegiatan penyuluhan dalam bentuk konseling kelompok dengan tujuan untuk mengembangkan sikap tanggap bencana kepada siswa sekolah yang lokasinya bersebelahan dengan Sungai Ciliwung. Acara dimulai dengan pembukaan oleh pembawa acara dari SDN Sempur Kaler, tenaga pendidik sekaligus pembimbing grup teater, Ibu Euis, kemudian dilanjutkan dengan sambutan oleh kepala sekolah dan pemutaran profil sekolah kepada tamu undangan, orang tua murid, dan siswa/I Kelas 4 dan 5 SDN Sempur Kaler Bogor. Acara juga dimeriahkan dengan adanya penampilan 'pantomim' mengenai evakuasi bencana kebakaran dan drama musikal mengenai prosedur evakuasi banjir yang dilakukan oleh SDN Sempur Kaler bekerja sama dengan BPDB Bogor; kedua penampilan tersebut disajikan dengan menarik dan penuh canda tawa sehingga tamu undangan, orang tua murid, dan siswa/i ikut terbawa dalam suasana riang gembira sekaligus menambah pengetahuan baru mengenai penanggulangan bencana. Setelah puas menyaksikan persembahan dari SDN Sempur Kaler, siswa/i kelas 4 dan 5 SDN Sempur Kaler diajak bermain sambil belajar dengan 2 permainan dari UAI, yaitu Permainan Ular Tangga dan Kartu Kuartet. Selanjutnya siswa/i diberi pengarahan oleh mahasiswa yang bertugas sebagai fasilitator untuk membagi siswa ke dalam kelompok dalam masing-masing permainan.

Dalam Permainan Ular Tangga, siswa/i kelas 4 dan 5 dibagi menjadi 4 kelompok dengan jumlah satu kelompok 7 orang. Berikut teknis permainan ular tangga: 
1. 32 siswa/i dibagi menjadi 4 kelompokmasing-masing terdiri dari 8 orang.

2. 2 siswa/i dari 1 kelompok menjadi perwakilan untuk bermain di papan ular tangga, siswa lainnya membantu menjawab pertanyaan dan bergantian melempar dadu.

3. Di beberapa kotak pada papan ular tangga terdapat pertanyaan atau gambar yang harus di jawab oleh kelompok yang menempati kotak dalam ular tangga tersebut. Setiap kelompok diberikan waktu 30 detik untuk berdiskusi dan mulai menjawab pertanyaan.

4. Apabila dalam waktu 30 detik tidak bisa menjawab maka harus mundur 3 langkah.

5. Apabila menempati kotak permainan dengan gambar yang dihubungkan dengan kepala ular dan tangga akan diberlakukan peraturan sebagai berikut:

a. Saat menempati kotak yang ada gambar ular, apabila bisa menjawab pertanyaan maka tidak turun.

b. Saat menempati kotak yang ada gambar tangga, apabila bisa menjawab pertanyaan maka boleh naik.

6. Pemain yang menempati kotak paling jauh maka kelompoknya menang.

Permainan ini berlangsung selama satu setengah jam dan diakhiri dengan penentuan pemenang kelompok.

Sebelum permainan dimulai, fasilitator terlebih dahulu mengumpulkan siswa untuk duduk bersama dan bertanya apa yang siswa/i SDN Sempur Kaler ketahui tentang bencana alam dan penyebabnya. Dengan antusias siswa/i melontarkan jawaban mereka namun karena situasi yang ramai suasana cenderung kurang kondusif fasilitator meminta siswa untuk mengangkat tangannya terlebih dahulu sebelum menjawab. Dari 28 siswa, sekitar $18 \%$ yang berlomba-lomba dalam menjawab pertanyaan dan $71 \%$ yang bisa menyahut bersama temantemannya untuk menjawab pertanyaan. Setelah puas dengan jawaban dari siswa, fasilitator membacakan ketentuan permainan dan meminta perwakilan dari tiap kelompok untuk diundi dan mengetahui urutan bermain tiap kelompok.

Selama permainan, beberapa siswa tampak antusias dalam melempar dadu dan menjawab pertanyaan yang diberikan di papan maupun di lontarkan oleh fasilitator meskipun dalam satu kelompok sekitar $14 \%$ persen yang antusias menjawab dan membantu temannya yang bermain di kotak permainan. Pertanyaan yang bisa dijawab oleh siswa berkisar mengenai apa itu bencana alam, jenis-jenisnya, penyebab dan cara mencegah bencana tersebut. Selain itu, para siswa juga menyebutkan tahapan-tahapan dalam penanggulangan bencana serta pihak-pihak mana saja yang terlibat dalam upaya penanggulangan bencana. Para siswa juga mampu menyebutkan singkatan dari PRB dan API. Pada umumnya para siswa mengetahui tentang banjir, penyebab banjir, longsor dan penyebabnya, kegiatan memilah sampah, membuat lubang hidroponik, apa saja yang harus ada dalam tas keadaan darurat,

Dari beberapa pertanyaan yang diberikan, siswa mendapatkan kesulitan dengan menjawab pertanyaan seputar cuaca, iklim, dan musim serta mengenai pencemaran dengan gas rumah kaca dan jenis-jenis gas berbahaya dengan alasan belum mendapatkan pelajaran tersebut dari guru dan pihak terkait lainnya.

Dalam kegiatan ini hambatan yang dapat dirasakan adalah jumlah siswa yang berlebih dalam satu kelompok sehingga yang tidak bermain di arena permainan dan melempar dadu mulai berhamburan keluar dan duduk di belakang dan merasa bosan serta kurangnya partisipasi dari setiap siswa karena dalam satu kelompok ada siswa yang mendominasi jawaban dan ada pula yang dipercaya dengan temannya untuk menjawab setiap pertanyaan. Selain itu karena ruangan kelas yang terbuka sehingga siswa bebas keluar ruangan dan hanya kembali saat temannya memanggil untuk menjawab pertanyaan atau melempar dadu. Selain itu hambatan yang dirasakan ialah situasi dan kondisi yang kurang kondusif dikarenakan terdapat satu permainan lainnya yaitu permainan kartu kuartet bencana yang dilakukan persis di depan permainan ular tangga, alhasil suara yang dikeluarkan oleh para siswa maupun fasilitator kurang terdengar oleh satu dengan yang lainnya. Kondisi lokasi juga cenderung panas dan lembab, hal tersebut juga menjadi salah satu faktor beberapa siswa yang pergi keluar kelas.

Saran untuk permainan selanjutnya, akan lebih baik apabila bisa meminimalisir jumlah siswa dalam kelompok menjadi 4-5 siswa saja, agar semua bisa ikut berpartisipasi, ruangan dapat lebih terbuka sehingga siswa yang tidak bermain di arena permainan dapat berkumpul dengan kelompoknya dengan tertib, pertanyaan yang terdapat di kotak permainan atau fasilitator lebih beragam, acak dan spesifik agar mengetahui sejauh mana pengetahuan siswa dalam penanggulangan bencana. Selain itu, sebaiknya lokasi yang digunakan untuk area satu 
permainan dengan permainan yang lainnya diberikan jarak agar terciptanya situasi yang lebih kondusif.

Dalam permainan menggunakan kartu kuartet tema bencana siswa bermain kartu secara berkelompok dengan cara mengelompokkan kartu-kartu yang memiliki pesan yang satu kelompok. Adapun tema-tema yang terdapat dalam kartu kuartet bencana antara lain tentang jenis-jenis bencana alam, bencana non alam, istilah istilah bencana seperti kerentanan, kapasitas, ancaman, risiko dan sekolah aman.

Setiap kelompok didampingi oleh mahasiswa dan guru untuk menjelaskan mengenai isi kartu berikut dengan penjelasan menggunakan contoh-contoh konkret yang terdapat disekitar kehidupan siswa.

Berikut beberapa contoh kartu bencana yang digunakan untuk permainan kelompok.
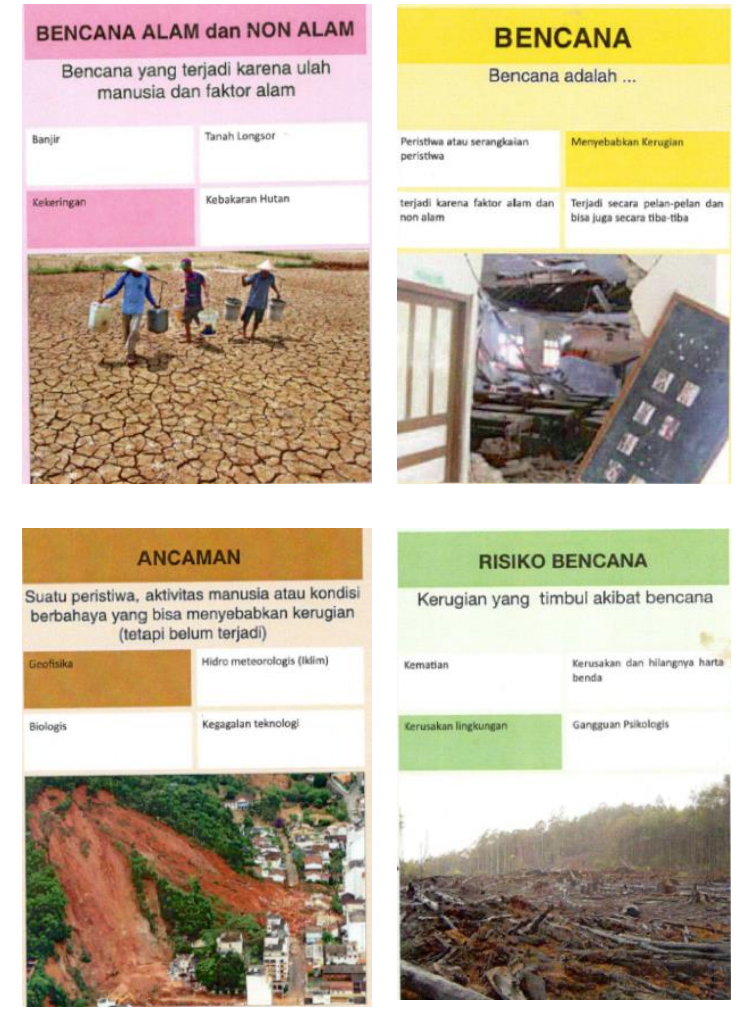

Gambar 1. Contoh kartu bencana

\section{SIMPULAN DAN SARAN}

Komunikasi terkait kesiapsiagaan bencana kepada siswa SD lebih efektif dilakukan melalui konseling kelompok dengan pendekatan permainan kelompok, drama musikal, dan pentas seni. Dari konseling melalui komunikasi kelompok, siswa memperoleh beberapa manfaat seperti: pemenuhan identitas diri, pertukaran informasi tentang bencana dari guru dan Badan Penanggulangan Bencana Daerah, kesempatan para siswa menunjukkan kemampuannya dalam berkreativitas serta siswa berkesempatan mengenal berbagai bentuk inovasi informasi tentang bencana serta belajar tentang perbedaan peran dalam pertolongan bencana.

\section{DAFTAR PUSTAKA}

Aminatun S, dan Muntafi Y. (2017, November). Kajian Analisis Risiko Bencana Tanah Longsor sebagai Dasar dalam Pembangunan Infrastruktur di Desa Sriharjo Kecamatan Imogiri Kabupaten Bantul. Jurnal Teknisia, XXII(2), 372-382.

BNPB. (2014). Indeks Risiko Bencana Indonesia Tahun 2013. Jakarta: Direktorat Pengurangan Risiko Bencana. BNPB. (2014, September). Komitmen Indonesia terhadap Implementasi HFA. Laporan Utama Majalah Gema BNPB, pp. 14-15.

Littlejhon, S. W., \& Foss, K. A. (2009). Encyclopedia of Communication Theory. California: Sage Publication Inc.

Miller, Khaterine. 2005. Communication Theories: Perspective, Process and Context, USA : Mc-Graw Hill Education.

Pace, R. W., \& Faules, D. F. (1994). Organizational Communication. 3rd ed. Englewood Cliffs. United State: NJ Prentice Hall.

Polee, M. S. (1999). Group Communication Theory Frey, Lawrence R, Goran, Dennis $S$, and Poole, Marshal Scott. California: Sage Publication Inc.

Saptadi, G., \& Djamal, H. (2012). Kajian Model Desa Tangguh Bencana dalam Kesiapsiagaan Penanggulangan Bencana Bersama BPBD Provinsi D.I Yogyakarta. Jurnal Penanggulangan Bencana, $B N P B, 3(2), 1-13$.

Sinulingga, Anita A, Apriwan, Haiyyu, Moenir Darman, (2014), Kepemerin tahan Bencana di Suma tera Barat. Jurnal Penanggulangan Bencana, Volume 5 no 
Pelayanan Konseling Melalui Komunikasi Kelompok untuk Pengurangan Risiko Bencana Bagi Siswa Sekolah Aman Bencana di Kota Bogor Jawa Barat

2, 2014 ISSN 2087636X, Badan Nasional Penanggulangan Bencana

Sunarti, E., Sumarno, H., \& Johan, I. R. (2013). Evaluasi Penanggulan Bencana, Pembelajaran Peran Pusat Studi Bencana IPB dalam Penanggulangan Bencana. Bogor: IPB Press.
Syamsiah, N. M. (2017). Kontribusi Pemangku Kepentingan untuk Penurunan Tingkat Risiko Bencana. Depok: UI Press. 